\title{
Palmitate and Glycerol Kinetics during Brief Starvation in Normal Weight Young Adult and Elderly Subjects
}

\author{
Samuel Klein,"¥ Vernon R. Young," George L. Blackbum,‡ Bruce R. Bistrian,‡ and Robert R. Wolfes \\ * Laboratory of Human Nutrition, Department of Applied Biological Sciences and Clinical Research Center, Massachusetts Institute of \\ Technology, Cambridge, Massachusetts 02139; ¥Nutrition and Metabolism Laboratory, New England Deaconess Hospital, Harvard \\ Medical School, Boston, Massachusetts 02215; §The University of Texas Medical Branch and Shriners Burns Institute,
} Galveston, Texas 77550

\begin{abstract}
Data obtained in vitro suggest that the ability to mobilize fat decreases with age. We determined lipolytic rates in vivo in normal weight young adult (22-33 yr) and elderly (65-77 yr) subjects using a simultaneous infusion of $\left[1,2-{ }^{13} \mathrm{C}_{2}\right]$ palmitate and [ $\left.{ }^{2} \mathbf{H}_{5}\right]$ glycerol. The subjects were studied after a 12-h fast and again after 60-82 $\mathrm{h}$ of fasting. When lipolysis was expressed per unit of adipose tissue the values for the young adults were more than double those for the elderly $(P<0.05)$. However, the amount of body fat in the elderly was twice that of the young adults, so that lipolysis per unit of body weight was similar in both groups. These results demonstrate that lipolysis per unit of adipose tissue is lower in elderly subjects. This may be due to their increase in body fat, however, since the total amount of potential energy mobilized from adipose tissue was similar to that of the young adults.
\end{abstract}

\section{Introduction}

The process of aging is characterized by a continuous decline in the function of many physiological systems (1). A decreased response to beta adrenergic stimulation has been shown in a variety of tissues (2-4) including adipose tissue (5-9). A decreased lipolytic response to beta adrenergic stimulation has been demonstrated in vitro in older rats (5-9). Although the mechanism responsible for this change is not clear, studies with fat cell membranes (10) and isolated adipocytes (11) suggest that a reduction in adenylate cyclase activity is involved.

During starvation, the ability to mobilize FFA from adipose tissue for fuel is an important adaptive response for survival. Recent evidence suggests that an increase in epinephrine secretion from the adrenal medulla is at least partly responsible for the increase in lipolysis during starvation (12-15). Therefore, a decrease in epinephrine-induced lipolysis in the elderly could have significant clinical consequences during periods of food deprivation. This issue, however, has not been carefully studied and the lipolytic response to starvation in elderly humans is not known.

Address reprint requests to Dr. Wolfe, Shriners Burns Institute, 610 Texas Avenue, Galveston, TX 77550. Dr. Klein was a National Institutes of Health postdoctoral research fellow at Harvard Medical School, Boston, MA.

Received for publication 3 September 1985 and in revised form 7 April 1986.

J. Clin. Invest.

(c) The American Society for Clinical Investigation, Inc.

0021-9738/86/10/0928/06 $\$ 1.00$

Volume 78, October 1986, 928-933
The purpose of this study was to evaluate lipolytic rates in young adult and elderly subjects during brief starvation, and to relate those rates to the plasma levels of epinephrine. Lipolytic rates were measured with $\left[{ }^{2} \mathrm{H}_{5}\right]$ glycerol, and the mobilization of FFA was measured simultaneously with $\left[1,2-{ }^{13} \mathrm{C}_{2}\right]$ palmitic acid. Total body fat was determined by $\mathrm{H}_{2}{ }^{18} \mathrm{O}$ dilution to enable the expression of lipolysis as a function of total body fat as well as total body weight.

\section{Methods}

Six normal young adult male students and four elderly adults (Table I) consented to the study, which was approved by the Massachusetts Institute of Technology (MIT) Committee on the use of Humans as Experimental Subjects and the Policy and Executive Committees of the Clinical Research Center (CRC). Subjects with evidence of diabetes mellitus, coronary artery disease, hypertension (blood pressure $>140 / 90$ ), renal failure, liver disease, and those who were $>10 \%$ above or below ideal body weight were excluded.

Prior to the study, each subject consumed a weight-maintaining freechoice diet. After an overnight ( $12 \mathrm{~h}$ ) fast in the CRC, teflon catheters were placed percutaneously into the antecubital vein of one arm of each subject using local anesthesia (lidocaine, $1 \%$ ) for infusions, and into a contralateral dorsal hand vein for arterialized venous sampling, using the heated hand technique (17). The subjects rested for $60 \mathrm{~min}$ after catheter placement before baseline blood samples were drawn. [1,2${ }^{13} \mathrm{C}_{2}$ ]Palmitic acid (99.5 atom percent, $1,2-{ }^{13} \mathrm{C}$; MSD Isotopes, Montreal, Canada) bound to essentially fatty acid-free human albumin (Cutter Laboratories, Emeryville, CA) (18) and $\left[{ }^{2} \mathrm{H}_{5}\right]$ glycerol (99 atom percent deuterium; MSD Isotopes), dissolved in normal saline, were mixed and infused together using a calibrated syringe pump (Harvard Apparatus Co., Inc., Natick, MA). Both the palmitic acid and glycerol solutions were tested for sterility and the absence of pyrogens by a licensed commercial laboratory before infusion. The palmitic acid was administered by constant infusion at a rate of $\sim 0.04 \mu \mathrm{mol} / \mathrm{kg}$ per min and the glycerol was infused via the primed-constant infusion technique $(19,20)$ using a priming dose of $1.6 \mu \mathrm{mol} / \mathrm{kg}$ and infusion rate of $0.11 \mu \mathrm{mol} / \mathrm{kg}$ per min. The infusion continued for $90 \mathrm{~min}$ while the subjects were kept supine and as undisturbed as possible.

The young subjects continued to fast for another $72 \mathrm{~h}(82 \mathrm{~h}$ total), while the elderly subjects fasted for another $48 \mathrm{~h}(60 \mathrm{~h}$ total). They were given only water, vitamins, $\mathrm{KCl}$, and $\mathrm{NaCl}$ orally. On the second day of fasting, blood samples were obtained before and $4 \mathrm{~h}$ after the oral administration of $\mathrm{H}_{2}{ }^{18} \mathrm{O}$ ( 10.45 atom percentage excess, Icon Services, Inc., Summit, NJ) to measure total body water (TBW). ${ }^{1}$ The $\mathrm{H}_{2}{ }^{18} \mathrm{O}$ was administered at a dose calculated to produce an increase of $\mathbf{4 0}$ parts per thousand in body $\mathrm{H}_{2}{ }^{18} \mathrm{O}$ concentration, and was weighed to the nearest $0.1 \mathrm{mg}$. The infusion protocol was repeated at the end of the starvation period before the resumption of caloric intake. Since there are no pub-

1. Abbreviations used in this paper: BF, body fat; GCMS, gas chromatography-mass spectrometry; LPM, lean body mass; MPE, mole percent excess; $R_{\mathrm{a}}$, rate of release; TBW, total body water. 
Table I. Characteristics (Mean \pm SE) of the Young Adult and Elderly Subjects

\begin{tabular}{lrr}
\hline & Young adults & \multicolumn{1}{c}{ Elderly } \\
\hline Age (years) & $24 \pm 2$ & $70 \pm 3$ \\
Height $(\mathrm{cm})$ & $181 \pm 2$ & $171 \pm 2$ \\
Weight $(\mathrm{kg})$ & $72 \pm 3$ & $72 \pm 3$ \\
Lean body mass $(\mathrm{kg})$ & $60 \pm 3$ & $46 \pm 3$ \\
Total body fat $(\mathrm{kg})$ & $11 \pm 1$ & $23 \pm 2$ \\
Fat (\% body wt) & $16 \pm 1$ & $33 \pm 2$ \\
\hline
\end{tabular}

lished reports of experimental fasting in elderly individuals for longer than $24 \mathrm{~h}$ and in vitro data suggest an impairment in lipolysis, it was decided to limit the duration of the fast in this age group to a maximum of $60 \mathrm{~h}$.

Baseline blood samples were drawn before the onset of the stable isotope infusion and again after isotopic equilibrium was established at $45,60,70,80$, and $90 \mathrm{~min}$. Two baseline blood samples for catecholamine determination were collected $5 \mathrm{~min}$ apart in iced tubes containing heparin and reduced glutathione. These were centrifuged immediately at $4^{\circ} \mathrm{C}$ and the supernatant divided into two 2.5 -ml aliquots, which were frozen in an acetone bath containing dry ice. The samples were stored at $-70^{\circ} \mathrm{C}$ until the time of analysis. Plasma norepinephrine and epinephrine concentrations were measured by reverse-phase liquid chromatography (21). Plasma levels of insulin were determined by radioimmunoassay $(22,23)$ using an Amersham kit (code IM.78, Amersham Corp., Arlington Heights, IL) for the younger subjects and a Micromedic kit (Micromedic Systems, Inc., Horsham, PA) for the elderly. Whole-blood glucose and beta hydroxybutyrate were determined enzymatically (24).

Blood for analysis of $\left[1,2-{ }^{13} \mathrm{C}_{2}\right]$ palmitic acid enrichment was collected in heparinized tubes and immediately placed in a $4^{\circ} \mathrm{C}$ ice bath. This procedure effectively prevents the in vitro hydrolysis of endogenous triglycerides by heparin-activated lipoprotein lipase (25). The plasma was promptly separated by centrifugation and stored at $-20^{\circ} \mathrm{C}$ until the time of analysis. The samples were processed for quantitative gas chromatography as described by McDonald-Gibson and Young (26). After conversion to the methyl esters, $\left[1,2-{ }^{13} \mathrm{C}_{2}\right]$ palmitic acid enrichment was determined by gas chromatography and mass spectrometry (GCMS) as described by Wolfe et al. (18) using a GCMS system (Hewlett-Packard 5985, Palo Alto, CA). Gas chromatographic separation of the fatty acid methyl esters was performed on a $3 \mathrm{ft} \times 2 \mathrm{~mm}$ glass column packed with 5\% diethylene-glycolsuccinate on a 100-200 mesh Supelcoport (Supelco, Inc., Bellefonte, PA) with the column temperature at $190^{\circ} \mathrm{C}$ and the helium carrier gas flow rate at $30 \mathrm{ml} / \mathrm{min}$. Ions at mass-to-charge ratios of 270.2 and 272.2, representing the molecular ions of unlabeled and $\left[1,2-{ }^{13} \mathrm{C}_{2}\right]$ palmitic acid methyl esters, respectively, were selectively monitored at $0.1-\mathrm{s}$ intervals and their corresponding peaks integrated. Palmitic acid concentration was quantitated separately on a gas chromatograph.

The blood for glycerol evaluation was collected in the same manner as that for palmitate. Plasma proteins were precipitated with $\mathrm{Ba}(\mathrm{OH})_{2}$ and $\mathrm{ZnSO}_{4}$ and the resultant supernatant passed through anion (Dowex AGI-X8) and cation (Dowex AG-50W-X8) exchange columns. The trimethylsilyl derivative was formed and ${ }^{2} \mathrm{H}$-enrichment determined by GCMS (27). Glycerol concentration was measured on an aliquot of the preinfusion sample by the internal standard technique using $\left[{ }^{2} \mathrm{H}_{5}\right]$ glycerol as the internal standard and GCMS analysis to determine concentration.

TBW was measured by $\mathrm{H}_{2}{ }^{18} \mathrm{O}$ dilution as described by Schoeller et al. (28). ${ }^{18} \mathrm{O}$ enrichment was analyzed on a triple inlet, triple collector, isotope ratio mass spectrometer (Nuclide Corp., State College, PA).

\section{Calculations}

The $R_{\mathbf{a}}$ of palmitate and glycerol into plasma were calculated according to Steele's equation (29) as it applies to isotopic steadystate conditions. Thus, the $R_{\mathbf{a}}$ of the substrate is:
$R_{\mathrm{a}}(\mu \mathrm{mol} / \mathrm{kg} \operatorname{per} \min )=\frac{\mathrm{F}}{\mathrm{IE}}$,

where $F$ is the isotope infusion rate ( $\mu \mathrm{mol} / \mathrm{kg}$ per min) and IE is the isotopic enrichment at plateau. Since the infusion of stable isotopes contributed up to $2 \%$ to the mass of the substrate pool the above equation is corrected to:

$R_{\mathrm{a}}(\mu \mathrm{mol} / \mathrm{kg}$ per min $)=\left(\frac{\mathrm{IE}_{\mathrm{i}}}{\mathrm{IE}_{\mathrm{p}}}-1\right) \times \mathrm{F}$,

where $R_{\mathrm{a}}$ is the rate of appearance of palmitate or glycerol, $\mathrm{IE}_{\mathrm{i}}$ is the isotopic enrichment of the infusate (atom percent excess) and $\mathrm{IE}_{\mathrm{p}}$ is the isotopic enrichment of plasma (atom percent excess) at isotopic equilibrium.

When substrate concentrations are not changing and when isotopic equilibrium is reached:

Substrate uptake $=R_{\mathrm{a}}(\mu \mathrm{mol} / \mathrm{kg}$ per $\mathrm{min})$

and the clearance rate of a substrate:

Substrate (palmitate or glycerol) clearance

Substrate uptake

$=\overline{\text { Substrate plasma concentration }}$.

Since palmitate is thought to be typical of other long-chain fatty acids $(30,31)$, the flux of all fatty acids is assumed to be similar to that of palmitate.

The concentration of plasma glycerol was determined as follows:

Unlabeled glycerol $(\mu \mathrm{mol} / \mathrm{ml})=\frac{0.007 \mu \mathrm{mol} / \mathrm{ml}}{\mathrm{MPE}}-0.007 \mu \mathrm{mol} / \mathrm{ml}$,

where $0.007 \mu \mathrm{mol} / \mathrm{ml}$ is the concentration of isotope $\left(\left[{ }^{2} \mathrm{H}_{5}\right]\right.$ glycerol $)$ added to $1 \mathrm{ml}$ of the preinfusion, baseline plasma sample, and MPE is the mole percent excess equal to $R / R+1$, where $R$ is equal to the final isotopic enrichment of the plasma minus the plasma enrichment before 0.007 $\mu$ mol of labeled glycerol was added.

The estimation of body fat was derived from the calculation of TBW as follows:

$\mathrm{TBW}(\mathrm{kg})=\frac{\mathrm{D}}{\mathrm{MW}} \times \frac{\mathrm{APE}}{100} \times 18.02 \times \frac{\mathrm{f}}{\mathrm{R}_{\mathrm{dad}} \times \Delta \delta^{18} \mathrm{O}}$,

where $\mathrm{D}$ is the dose of $\mathrm{H}_{2}{ }^{18} \mathrm{O}(\mathrm{g}), \mathrm{MW}$ is the molecular weight of the $\mathrm{H}_{2}{ }^{18} \mathrm{O}$, APE is the atom percentage ${ }^{18} \mathrm{O}$ enrichment of the $\mathrm{H}_{2}{ }^{18} \mathrm{O}, \mathrm{f}$ is the ${ }^{18} \mathrm{O}$ fractionation between $\mathrm{CO}_{2}$ and $\mathrm{H}_{2} \mathrm{O}$ (1.0407), $\mathrm{R}_{\mathrm{edd}}$ is the ratio of ${ }^{18} \mathrm{O} /{ }^{16} \mathrm{O}$ in the standard $(0.002045)$ and $\Delta \delta^{18} \mathrm{O}$ is the difference in enrichment in the plasma water resulting from the isotope administration. Once having calculated TBW, then:

Lean body mass $(\mathrm{kg})=\mathrm{TBW} / 0.72$

Body fat $(\mathbf{k g})=$ Body weight - lean body mass

\section{Statistical analysis}

The Student's $t$ test for paired comparisons was used to test the significance of changes in palmitate flux, glycerol flux, insulin levels, and substrate concentrations before and after fasting. Differences between the young adults and elderly were evaluated by the Student's $t$ test for independent samples. An analysis of variance (ANOVA) was used to test the significance of changes in norepinephrine and epinephrine levels before and after fasting (32). One-sided $P$ values were used when evaluating changes in palmitate and glycerol release since these processes should always increase with starvation. All other reported $\boldsymbol{P}$ values are based on twosided tests.

\section{Results}

Young adults. Approximately $16 \%$ of total body weight consisted of adipose tissue (Table I). This is similar to the average fat 
Table II. Response of Metabolic Factors (Mean $\pm S E$ ) to an 82-h Fast in Young Adults

\begin{tabular}{|c|c|c|c|}
\hline & Overnight fast & 82-h fast & $P$-value \\
\hline Body weight $(\mathrm{kg})$ & $71.2 \pm 2.8$ & $68.5 \pm 2.9$ & 0.001 \\
\hline Glucose (mmol/liter) & $5.15 \pm 0.25$ & $3.41 \pm 0.10$ & 0.001 \\
\hline Beta hydroxybutyrate (mmol/liter) & $0.08 \pm 0.04$ & $3.01 \pm 0.64$ & $<0.005$ \\
\hline Insulin $(\mu U / m l)$ & $8.1 \pm 0.9$ & $3.0 \pm 0.8$ & $<0.05$ \\
\hline Epinephrine $(p g / m l)$ & $53 \pm 7$ & $76 \pm 11$ & 0.01 \\
\hline Norepinephrine $(p g / m l)$ & $238 \pm 19$ & $277 \pm 26$ & NS \\
\hline Glycerol $(\mu \mathrm{mol} / \mathrm{ml})$ & $0.040 \pm 0.007$ & $0.087 \pm 0.011$ & 0.01 \\
\hline Palmitate $(\mu \mathrm{mol} / \mathrm{ml})$ & $0.052 \pm 0.008$ & $0.162 \pm 0.012$ & $<0.001$ \\
\hline$R_{\mathrm{a}}$ of glycerol $(\mu \mathrm{mol} / \mathrm{kg} \mathrm{per} \mathrm{min})$ & $2.59 \pm 0.22$ & $5.04 \pm 0.28$ & $<0.001^{*}$ \\
\hline$R_{\mathrm{a}}$ of glycerol $(\mu \mathrm{mol} / \mathrm{kg} B F$ per min) & $17.04 \pm 1.16$ & $34.21 \pm 4.21$ & $<0.005^{*}$ \\
\hline$R_{\mathrm{a}}$ of glycerol per $(\mu \mathrm{mol} / \mathrm{kg} L B M$ per $\mathrm{min})$ & $3.08 \pm 0.26$ & $5.97 \pm 0.33$ & $<0.001^{*}$ \\
\hline$R_{\mathrm{a}}$ of palmitate $(\mu \mathrm{mol} / \mathrm{kg}$ per $\mathrm{min})$ & $1.86 \pm 0.18$ & $4.02 \pm 0.13$ & $<0.001^{*}$ \\
\hline$R_{\mathrm{a}}$ of palmitate $(\mu \mathrm{mol} / \mathrm{kg}$ BF per min) & $12.73 \pm 2.03$ & $27.48 \pm 3.29$ & $<0.005^{*}$ \\
\hline$R_{\mathrm{a}}$ of palmitate $(\mu \mathrm{mol} / \mathrm{kg} L B M$ per $\mathrm{min})$ & $2.24 \pm 0.23$ & $4.76 \pm 0.16$ & $<0.001^{*}$ \\
\hline Glycerol clearance $(\mathrm{ml} / \mathrm{kg}$ LBM per $\mathrm{min})$ & $84 \pm 11$ & $76 \pm 15$ & NS \\
\hline Palmitate clearance ( $\mathrm{ml} / \mathrm{kg}$ LBM per min) & $73 \pm 10$ & $50 \pm 7$ & NS \\
\hline
\end{tabular}

* One-sided $P$ value.

content reported previously in young adult men (33). The changes in various metabolic and hormonal factors in response to several days of fasting are shown in Table II. Weight loss was progressive throughout the fasting period. The mean $( \pm \mathrm{SE})$ concentration of blood glucose decreased from $5.15 \pm 0.25$ to $3.14 \pm 0.10 \mathrm{mmol} /$ liter with continued fasting $(P<0.001)$, as did the level of insulin (from $8.1 \pm 0.9$ to $3.0 \pm 0.8 \mu \mathrm{U} / \mathrm{ml})(P<0.05$ ). These data are in agreement with previous reports $(34,35)$. The concentration of beta hydroxybutyrate (Table II) increased markedly with accelerated lipolysis from $0.08 \pm 0.04 \mathrm{mmol} /$ liter to $3.01 \pm 0.64 \mathrm{mmol} /$ liter $(P<0.005)$.

The overall mean ( $\pm \mathrm{SE}) R_{\mathrm{a}}$ of palmitate after the overnight fast (Table II), was $1.86 \pm 0.18 \mu \mathrm{mol} / \mathrm{kg}$ per min and doubled to $4.02 \pm 0.13 \mu \mathrm{mol} / \mathrm{kg}$ per min after $82 \mathrm{~h}$ of fasting $(P<0.001)$. When lipolysis is expressed per unit of body fat (BF), the mean $R_{\mathrm{a}}$ of palmitate increased from $12.73 \pm 2.03 \mu \mathrm{mol} / \mathrm{kg} \mathrm{BF}$ per min after an overnight fast to $27.48 \pm 3.29 \mu \mathrm{mol} / \mathrm{kg} \mathrm{BF}$ per min with starvation $(P<0.005)$. The mean $( \pm \mathrm{SE})$ amount of palmitate released into the bloodstream for possible utilization by the LBM was $2.24 \pm 0.23 \mu \mathrm{mol} / \mathrm{kg} \mathrm{LBM}$ per min after the overnight fast and $4.76 \pm 0.16 \mu \mathrm{mol} / \mathrm{kg} \mathrm{LBM}$ per min after $82 \mathrm{~h}$ of starvation $(P<0.001)$.

The mean $( \pm \mathrm{SE}) R_{\mathrm{a}}$ of glycerol after the overnight fast was $2.59 \pm 0.22 \mu \mathrm{mol} / \mathrm{kg}$ per $\min (24 \mathrm{~g} / \mathrm{d})$, which doubled to $5.04 \pm 0.28 \mu \mathrm{mol} / \mathrm{kg}$ per $\min (46 \mathrm{~g} / \mathrm{d})$ with prolonged fasting $(P$ $<0.001$ ). When lipolysis was expressed per unit of $B F$, the mean $R_{\mathrm{a}}$ of glycerol increased from $17.04 \pm 1.16$ to $34.21 \pm 4.21 \mu \mathrm{mol} /$ $\mathrm{kg}$ BF per min with starvation $(P<0.005)$. The mean $R_{\mathrm{a}}$ of glycerol per $\mathrm{kg}$ LBM was $3.08 \pm 0.26$ and $5.97 \pm 0.33$ after the overnight and 82-h fasts, respectively $(P<0.001)$.

Although the mean concentration of plasma glycerol doubled from $0.040 \pm 0.007$ to $0.087 \pm 0.011 \mu \mathrm{mol} / \mathrm{ml}(P<0.01)$ and the mean total plasma palmitate increased threefold from $0.052 \pm 0.008$ to $0.162 \pm 0.012 \mu \mathrm{mol} / \mathrm{ml}(P<0.001)$, there was no statistically significant change in the relative rates of plasma glycerol or palmitate clearance (Table II). The rate of uptake of glycerol and palmitate thus increased in proportion to the change in plasma concentrations of these substrates.
The mean levels of plasma catecholamines are also displayed in Table II. Plasma epinephrine increased by $43 \%$, from $53 \pm 7$ to $76 \pm 11 \mathrm{pg} / \mathrm{ml}$ with continued starvation $(P=0.01)$. Plasma norepinephrine also increased slightly (by $16 \%$ ), but the difference was not statistically significant.

Elderly subjects. The elderly subjects fasted for a total of 60 $\mathrm{h}, 22 \mathrm{~h}$ less than the young adult subjects. In general, the elderly group tolerated the fast quite well without major complaints of hunger or weakness. The percentage of body weight as fat (33\%) was twice that of the young adults (Table I). This is similar to the average fat content in elderly subjects reported previously (33). Table III summarizes the various metabolic changes occurring in this group during starvation. None of the factors listed in this table, after an overnight fast, were significantly different from the younger group. There was little decrease in body weight during the $60-\mathrm{h}$ fast. The decrease in blood glucose $(P=0.001)$ and increase in beta hydroxybutyrate $(P<0.05)$ were similar to those observed in the younger subjects. The mean plasma insulin concentration declined from $6.1 \pm 0.5$ to $4.6 \pm 0.2 \mu \mathrm{U} / \mathrm{ml}$ with continued fasting $(P<0.05)$. The plasma concentrations and plasma clearances of glycerol and palmitate after the overnight and $60-\mathrm{h}$ fasting periods were similar to those found in the younger subjects.

The mean ( $\pm \mathrm{SE}$ ) $R_{\mathrm{a}}$ of palmitate (Table III) was $1.93 \pm 0.30$ $\mu \mathrm{mol} / \mathrm{kg}$ per min after an overnight fast and doubled to $3.91 \pm 0.33 \mu \mathrm{mol} / \mathrm{kg}$ per min after $60 \mathrm{~h}$ of starvation $(P<0.05)$. This response was similar to that found for young adults, despite a somewhat shorter fast. The mean $( \pm \mathrm{SE}) R_{\mathrm{a}}$ of palmitate per unit of LBM was also similar to the young adults (Table III). When lipolysis was expressed per unit of body fat, however, the release of palmitate was less than half that of the young adults $(P<0.05)$. The mean $R_{\mathrm{a}}$ of palmitate was $5.30 \pm 1.22$ and $11.64 \pm 0.62 \mu \mathrm{mol} / \mathrm{kg}$ BF per min after the overnight and $60-\mathrm{h}$ fasts, respectively $(P<0.05)$.

As in the younger subjects, the mean $R_{\mathrm{a}}$ of glycerol was about equimolar to that of palmitate. The average $R_{\mathrm{a}}$ of glycerol was $2.19 \pm 0.16 \mu \mathrm{mol} / \mathrm{kg}$ per min after the overnight fast and increased to $3.84 \pm 0.36 \mu \mathrm{mol} / \mathrm{kg}$ per min after $60 \mathrm{~h}$ of fasting $(P=0.005)$. 
Table III. Response of Metabolic Factors (Mean $\pm S E$ ) to a 60-h Fast in Elderly Subjects

\begin{tabular}{|c|c|c|c|}
\hline & Overnight fast & 60-h Fast & $P$ Value \\
\hline Body weight $(k g)$ & $71.8 \pm 2.8$ & $71.2 \pm 2.9$ & NS \\
\hline Glucose (mmol/liter) & $5.26 \pm 0.24$ & $3.14 \pm 0.17$ & 0.001 \\
\hline Beta hydroxybutyrate (mmol/liter) & $0.07 \pm 0.001$ & $3.01 \pm 0.80$ & $<0.05$ \\
\hline Insulin $(\mu U / m l)$ & $6.1 \pm 0.5$ & $4.6 \pm 0.2$ & $<0.05$ \\
\hline Epinephrine $(p g / m l)$ & $41 \pm 8$ & $63 \pm 10$ & $<0.01$ \\
\hline Norepinephrine $(\mathrm{pg} / \mathrm{ml})$ & $307 \pm 56$ & $396 \pm 77$ & $<0.01$ \\
\hline Glycerol $(\mu \mathrm{mol} / \mathrm{ml})$ & $0.048 \pm 0.004$ & $0.086 \pm 0.016$ & NS \\
\hline Palmitate $(\mu \mathrm{mol} / \mathrm{ml})$ & $0.075 \pm 0.020$ & $0.194 \pm 0.040$ & $<0.05$ \\
\hline$R_{\mathrm{a}}$ of glycerol $(\mu \mathrm{mol} / \mathrm{kg}$ per $\mathrm{min})$ & $2.19 \pm 0.16$ & $3.84 \pm 0.36$ & $0.005^{*}$ \\
\hline$R_{\mathrm{a}}$ of glycerol $(\mu \mathrm{mol} / \mathrm{kg}$ BF per min) & $7.03 \pm 0.64$ & $12.54 \pm 0.49$ & $<0.05^{*}$ \\
\hline$R_{\mathrm{a}}$ of glycerol $(\mu \mathrm{mol} / \mathrm{kg} L \mathrm{LB}$ per $\mathrm{min})$ & $3.49 \pm 0.30$ & $6.32 \pm 0.65$ & $<0.05^{*}$ \\
\hline$R_{\mathrm{a}}$ of palmitate $(\mu \mathrm{mol} / \mathrm{kg}$ per $\mathrm{min})$ & $1.93 \pm 0.30$ & $3.91 \pm 0.33$ & $<0.05^{*}$ \\
\hline$R_{\mathrm{a}}$ of palmitate $(\mu \mathrm{mol} / \mathrm{kg} \mathrm{BF}$ per min) & $5.30 \pm 1.22$ & $11.64 \pm 0.62$ & $<0.05^{*}$ \\
\hline$R_{\mathrm{a}}$ of palmitate $(\mu \mathrm{mol} / \mathrm{kg} L B M$ per min $)$ & $2.52 \pm 0.34$ & $6.00 \pm 0.95$ & $<0.05^{*}$ \\
\hline Glycerol clearance (ml/kg LBM per min) & $72 \pm 5$ & $68 \pm 11$ & NS \\
\hline Palmitate clearance ( $\mathrm{ml} / \mathrm{kg}$ LBM per $\mathrm{min})$ & $58 \pm 13$ & $40 \pm 1$ & NS \\
\hline
\end{tabular}

* One-sided $P$ value.

When the $R_{\mathrm{a}}$ of glycerol is expressed per unit of body fat, it is again less than half that of the young adults $(P<0.05)$. The mean $R_{\mathrm{a}}$ of glycerol was $7.03 \pm 0.64$ and $12.54 \pm 0.49 \mu \mathrm{mol} / \mathrm{kg}$ BF per min after the overnight and 60 -h fasts, respectively $(P<0.05)$.

The concentration of plasma catecholamines increased significantly after $60 \mathrm{~h}$ of starvation when compared to that after the overnight fast. The mean concentration of plasma epinephrine increased by $54 \%$ from $41 \pm 8$ to $63 \pm 10 \mathrm{pg} / \mathrm{ml}(P<0.01)$ and that of norepinephrine by $29 \%$ from $307 \pm 56$ to $396 \pm 77$ $\mathrm{pg} / \mathrm{ml}(P<0.01)$.

\section{Discussion}

The results of this study are consistent with observations made previously in isolated rat adipocytes (5-9). Lipolysis per unit of adipose tissue was much lower in the elderly subjects than in the normal volunteers after both the overnight and the more prolonged period of fasting. As in rats (36), however, the percentage of body fat in the elderly (33\%) was more than twice that of the young adults (16\%), so that whole-body lipolytic rates were similar in both groups. Furthermore, the amount of potential energy supplied from fat in relation to the LBM was also similar in both groups.

The mechanism regulating this process is not known but could be related to the energy needs of the LBM. Therefore, the lower rate of lipolysis per unit of adipose tissue in the elderly may be a reflection of their proportionate increase in body fat rather than their increase in age. Without some regulatory mechanism, individuals with excess body fat would release large amounts of FFA into the bloodstream during fasting. This would not only exceed energy requirements, but could become hazardous if fatty acid binding sites on albumin were overwhelmed (37). In vivo studies performed in young adult obese subjects revealed similar results (38). Lipolysis per unit of BF was much lower in the obese when compared with normal weight subjects. The amount of fatty acids released per unit of LBM was similar, however, in both groups.
The mean release of palmitate from adipose tissue into plasma approximately doubled with the 60 - or 80 -h fasts. Since palmitate is typical of other fatty acids and usually constitutes $\sim 25 \%$ of total circulating fatty acids (31), the rate of lipolysis at the end of the fasting period represents $\sim 4,000 \mathrm{kcal}$ of potential energy released into the circulation per day. This exceeds daily energy needs and supports previous observations that only a portion of the FFA flux is oxidized for fuel $(39,40)$.

The average $R_{\mathrm{a}}$ of glycerol after an overnight fast amounts to $24 \mathrm{~g}$ released into the plasma per day in the young subjects and $21 \mathrm{~g} / \mathrm{d}$ in the elderly. This correlates well with other reports using different methodology (41). Glycerol release increased after further starvation, but was still less than $50 \mathrm{~g} / \mathrm{d}$. Even if all of the glycerol released from adipose tissue were used solely for gluconeogenesis, this would amount to the production of $<25$ $\mathrm{g}$ of glucose/d. The amount of glucose utilized by the brain and other tissues during this period of starvation is much higher (42). This explains, in part, why nitrogen loss continues throughout starvation, since gluconeogenesis from amino acids must occur to meet the body's glucose requirement.

Even though the plasma concentration of palmitate and glycerol increased during starvation, plasma clearance for these substrates did not change. This confirms that the higher concentrations of palmitate and glycerol resulted from an increase in release from adipose tissue and not from a decrease in their clearance.

The increase in plasma epinephrine during fasting is consistent with the view that fasting stimulates the secretion of epinephrine from the adrenal medulla, which results in an increase in lipolysis (14). However, the level of plasma epinephrine observed in this study remained below the reported threshold level for lipolysis $(43,44)$. If this modest increase in plasma epinephrine does stimulate lipolysis, the lipolytic response to epinephrine must be increased. It has been shown that starvation increases epinephrine-induced lipolysis in humans (45) and increases epinephrine-stimulated adenylate cyclase activity in rats (46). Furthermore, the decrease in plasma insulin may enhance epinephrine-induced lipolysis. When insulin is deficient as in strepto- 
zotocin-induced diabetic rats, adipose tissue is 5-10 times more sensitive to the lipolytic action of epinephrine than adipose tissue from normal rats (47).

The plasma concentration of norepinephrine increased with starvation in both the young and old subjects, but this increase was only statistically significant in the elderly. It is unlikely that the sympathetic nervous system is involved in lipolysis during starvation. Since norepinephrine functions mainly as a neurotransmitter in sympathetic nerve endings, dynamic measurements of norepinephrine turnover may be required to assess sympathetic nervous system activity (48). A decrease in norepinephrine turnover has been demonstrated in animals during starvation (49) and in humans during hypocaloric feeding (50). Increased urinary excretion of norepinephrine may occur during starvation but is eliminated by adrenalectomy (14). Therefore, the increase of plasma norepinephrine levels observed in the present study may be explained by an increased secretion of norepinephrine from the adrenal medulla.

In conclusion, adipose tissue can supply all of the daily caloric needs during starvation in both young adult and elderly subjects by increasing the rate of lipolysis. Although lipolysis per unit of adipose tissue is lower in elderly subjects during brief starvation, this may reflect their increase in body fat since the whole-body release of fatty acids and glycerol was similar to the young adults.

\section{Acknowledgments}

The authors greatly appreciate the support of the CRC staff and the willingness of the volunteers to undertake this study. We thank Mr. Frank Mitrano for his help in the preparation of the isotopes, Sarada Kunapuli for her technical assistance, Judy Chadwick for the preparation of this manuscript, and Drs. James Young and Lewis Landsberg for the determination of the plasma catecholamines and their suggestions during this project. We are also indebted to Marta Wolfe for the analysis of samples by gas chromatography and mass spectrometry.

This research was supported by National Institutes of Health grants T32-CA09459, AM-31933, AM-34817, and RR-88 and a grant from the Shriners Hospitals.

\section{References}

1. Masaro, E. J., H. A. Bertrand, G. Lieps, and B. P. Yu. 1979. Analysis and exploration of age-related changes in mammalian structure and function. Fed. Proc. 38:1956-1961.

2. Feldman, R. D., L. E. Limbird, J. Nadear, D. Robertson, and A. J. J. Wood. 1984. Alterations in leukocyte beta-receptor affinity with aging. N. Engl. J. Med. 310:815-819.

3. Lakatta, E. G. 1980. Age related alterations in the cardiovascular response to adrenergic mediated stress. Fed. Proc. 39:3173-3177.

4. Abrass, I. B., J. L. Davis, and S. Carpace. 1982. Isoproterenol responsiveness and myocardial beta-adrenergic receptors in young and old rats. J. Gerontol. 37:156-160.

5. Benjamin, W., A. Gelhorn, M. Wagner, and H. Kundel. 1961. Effect of aging on lipid composition and metabolism in the adipose tissue of the rat. Am. J. Physiol. 201:540-546.

6. Nakano, J., A. C. Gin, and T. Ishii. 1971. Effect of age on norepinephrine-, ACTH-, theophylline-, and dibutryl cyclic AMP induced lipolysis in isolated rat fat cells. J. Gerontol. 26:8-12.

7. Yu, B. P., H. A. Bertrand, and E. J. Masaro. 1980. Nutritionaging influence of catecholamine-promoted lipolysis. Metab. Clin. Exp. 29:438-442.

8. Dax, E. M., J. S. Partilla, and R. I. Gregerman. 1981. Mechanism of the age-related decrease of epinephrine-stimulated lipolysis in isolated rat adipocytes. Beta-adrenergic receptor binding, adenylate cyclase activity, and cyclic AMP accumulation. J. Lipid Res. 22:934-943.
9. Hoffman, B. B., H. Chang, Z. T. Farahbakhsk, and G. Reaven. 1984. Age-related decrement in hormone-stimulated lipolysis. Am. J. Physiol. 247:E772-E777.

10. Cooper, B., and R. I. Gregerman. 1976. Hormone-sensitive fat cell adenylate cyclase in the rat. Influences of growth, cell size, and aging. J. Clin. Invest. 57:161-168.

11. Forn, J., P. S. Schomhofer, I. F. Skidmore, and G. Kuhna. 1970. Effect of aging on the adenyl cyclase and phosphodiesterase activity of isolated fat cells of rat. Biochim. Biophys. Acta. 208:304-309.

12. Young, J. B., and L. Lansberg. 1979. Sympathoadrenal activity in fasting pregnant rats: dissociation of adrenal medullary and sympathetic nervous system responses. J. Clin. Invest. 64:109-116.

13. Palmbad, J. L., L. Levi, A. Burger, A. Melander, V. Westgren, H. Von Schenck, and G. Skude. 1977. Effects of total energy withdrawal (fasting) on the levels of growth hormone, thyrotropin, cortisol, adrenaline, noradrenaline, $\mathrm{T}_{4}, \mathrm{~T}_{3}$ and $\mathrm{rT}_{3}$ in healthy males. Acta Med. Scand. 201:15-22.

14. Young, J. B., R. M. Rosa, and L. Landsberg. 1984. Dissociation of sympathetic nervous system and adrenal medullary responses. $\mathrm{Am}$. J. Physiol. (Endocrinol. Metab.) 10:E35-E40.

15. Zapf, J., M. Waldvogel, and E. R. Froesch. 1977. Increased sensitivity of rat adipose tissue to the lipolytic action of epinephrine during fasting and its reversal during refeeding. FEBS (Fed. Eur. Biochem. Soc.) Lett. 76:135-138.

16. Dax, E. M., J. S. Partilla, and R. I. Gregerman. 1981. Increased sensitivity to epinephrine stimulated lipolysis during starvation: tighter coupling of the adenylate cyclase complex. Biochem. Biophys. Res. Commun. 101:1186-1192.

17. McGuire, E. A. H., J. H. Helderman, J. D. Tobin, R. Andres, and M. Berman. 1976. Effects of arterial versus venous sampling on analysis of glucose kinetics in man. J. Appl. Physiol. 41:565-573.

18. Wolfe, R. R., J. E. Evans, C. J. Mullany, and J. F. Burke. 1980. Measurement of plasma free fatty acid turnover and oxidation using $1-{ }^{13}$ C-palmitic acid. Biomed. Mass Spectrom. 7:168-171.

19. Bortz, W. M., P. Paul, H. I. Miller, and W. M. Bortz. 1972. Glycerol turnover and oxidation in man. J. Clin. Invest. 51:1537-1546.

20. Wolfe, R. R. 1985. Tracers in Metabolic Research: Radioisotope and Stable Isotope/Mass Spectrometry Methods. Alan R. Liss, Inc., New York. 67-79.

21. David, G. C., and P. T. Kissinger. 1981. Strategies for determination of serum or plasma norepinephrine by reverse-phase liquid chromatography. Anal. Chem. 53:156-159.

22. Yalow, R. S., and S. A. Berson. 1960. Immunoassay of endogenous plasma insulin in man. J. Clin. Invest. 39:1157-1175.

23. Hales, C. N., and P. J. Randle. 1963. Immunoassay of insulin with insulin antibody precipitate. Biochem. J. 88:137-146.

24. Bergmeyer, H. V. 1974. Methods of Enzymatic Analysis. Academic Press, Inc., New York. 1196-1201; 1464-1468.

25. Schade, D. S., and R. P. Eaton. 1977. The regulation of plasma ketone body concentration by counter-regulatory hormones in man. I. Effects of norepinephrine in diabetic man. Diabetes. 26:989-996.

26. McDonald-Gibson, R. G., and M. Young. 1974. The use of automatic solids injection system for quantitative determination of plasma long-chain non-esterified fatty acids by gas-liquid chromatography. Clin. Chim. Acta. 53:117-126.

27. Wolfe, R. R. 1984. Tracers in Metabolic Research: Radioisotope and Stable Isotope/Mass Spectrometry Methods. Alan R. Liss, Inc., New York. 261-263.

28. Schoeller, D. A., E. Van Santen, D. W. Peterson, W. Dietz, J. Jaspan, and P. D. Klein. 1980. Total body water measurement in humans with ${ }^{18} \mathrm{O}$ and ${ }^{2} \mathrm{H}$ labeled water. Am. J. Clin. Nutr. 33:2686-2693.

29. Steele, R. 1959. Influences of glucose loading and of injected insulin on hepatic glucose output. Ann. NY Acad. Sci. 82:420-430.

30. Spitzer, J. J., and M. Gold. 1965. Studies on the metabolism of free fatty acids in diabetic and fasting dogs. Ann. NY Acad. Sci. 131: 235-249.

31. Hagenfeldt, L., J. Wahren, B. Pernow, and L. Raf. 1972. Uptake 
of individual free fatty acids by skeletal muscle and liver in man. J. Clin. Invest. 51:2324-2330.

32. Sokal, R. R., and F. J. Rohlf. 1969. Biometry. W. H. Freeman, San Francisco, CA. 299-356.

33. Lesser, G. T., S. Deutsch, and J. Markofski. 1971. Use of independent measurement of body fat to evaluate overweight and underweight. Metab. Clin. Exp. 20:792-804.

34. Lilavivathana, U., R. G. Campbell, and R. G. Brodows. 1978. Control of insulin secretion during fasting in man. Metab. Clin. Exp. 27:815-821.

35. Aguilar-Parade, E., A. M. Eisentraut, and R. H. Unger. 1969. Effects of starvation on plasma pancreatic glucagon in normal man. $D i$ abetes. 18:717-723.

36. Williams, H. H., N. Galbraithe, M. Kaucher, E. Z. Moyer, A. J. Richards, and I. G. Macy. 1945. The effect of growth on the lipid composition of rat tissues. J. Biol. Chem. 161:475-484.

37. Goodman, D. S. 1958. The interaction of human serum albumin with long-chain fatty acid anions. J. Am. Chem. Soc. 80:3892-3898.

38. Wolfe, R. R., E. J. Peters, S. Klein, B. Holland, and J. Rosenblatt. Effect of short-term fasting on the lipolytic responsiveness to epinephrine infusion in normal and obese human subjects. Am. J. Physiol. In press.

39. Armstrong, D. T., R. Steele, N. Altszuler, A. Dunn, J. S. Bishop, and R. C. DeBodo. 1961. Regulation of plasma free fatty acid turnover. Am. J. Physiol. 201:9-15.

40. Issekutz, B., Jr., P. Paule, H. I. Miller, and W. M. Bortz. 1968. Oxidation of plasma FFA in lean and obese humans. Metab. Clin. Exp. 17:62-73.

41. Cahill, G. F., Jr., M. G. Herrera, A. P. Morgan, J. S. Soelduer,
J. Steinke, P. L. Levy, G. A. Reichard, and D. M. Kipnis. 1966. Hormonefuel interrelationships during fasting. J. Clin. Invest. 45:1751-1769.

42. Cahill, G. F., Jr. 1976. Starvation in man. Clin. Endocrinol. Metab. 5:397-416.

43. Clutter, W. E., D. M. Bier, S. D. Shah, and P. E. Cryer. 1980. Epinephrine plasma metabolic clearance rates and physiologic thresholds for metabolic and hemodynamic actions in man. J. Clin. Invest. 66:94101.

44. Galster, A. D., W. E. Clutter, P. E. Cryer, J. A. Collins, and D. M. Bier. 1981. Epinephrine plasma thresholds for lipolytic effects in man. Measurements of fatty acid transport with $\left[1-{ }^{13} \mathrm{C}\right]$ palmitic acid. $J$. Clin. Invest. 67:1729-1738.

45. Wolfe, R. R., E. J. Peters, S. Klein, and B. Holland. 1985. Fasting enhances the lipolytic effect of epinephrine. Clin. Res. 33:721a. (Abstr.)

46. Gorman, R. R., H. M. Tepperman, and J. Tepperman. 1972. Effects of starvation, refeeding and fat feeding on adipocyte ghost adenyl cyclase activity. J. Lipid Res. 13:276-280.

47. Zapf, J., D. Feverlein, M. Waldvogel, and E. R. Froesch. 1975. Increased sensitivity of diabetic rat adipose tissue towards the lipolytic action of epinephrine. Diabetologia. 11:509-516.

48. Lansberg, L., and J. B. Young. 1978. Fasting, feeding and regulation of the sympathetic nervous system. N. Engl. J. Med. 198:12951301.

49. Young, J. B., and L. Lansberg. 1977. Suppression of sympathetic nervous system during fasting. Science (Wash. DC). 196:1473-1475.

50. O’Dea, K., M. Esler, P. Leonard, J. R. Stockigt, and R. Nestel. 1982. Noradrenaline turnover during under-and over-eating in normal weight subjects. Metab. Clin. Exp. 31:896-899. 